\title{
CFT3層骨組に組み込まれたスリット入り鋼板耐震壁の耐震性能 SEISMIC PERFORMANCE OF STEEL SHEAR WALL WITH SLITS
INCORPORATED IN THREE-STORY CFT BUILDING FRAME
}

\author{
日高桃子*1, 松井千秋*2, 堺 純一*3 \\ Toko HITAKA, Chiaki MATSUI and Junichi SAKAI
}

\begin{abstract}
Data obtained from a series of tests conducted to investigate seismic performance of multi-story CFT-column steel-beam building frames braced by steel shear walls with slits is analyzed to study behavior of the shear walls and its effect on the CFT frame. Test results are presented for six three-story one-bay frame specimens of roughly one-third scale, which were subjected to static cyclic lateral loading. These tests provide data on the behavior of shear walls installed in a building frame along height, as well as the braced frame's behavior. The test data indicate that stiffness is properly estimated summing the walls deformation and the rotation of the wall caused by beam's deformation. Expected maximum deformation of the walls must be considered to evaluate strength of the wall frame, reflecting the drift level.at which out-of-plane buckling of the wall plate occurs.
\end{abstract}

Keywords: steel shear wall with slits; multi-story continuous shear wall, concrete filled steel tubular, structural performance スリット入り鋼板耐震壁、連層而震壁、コンクリート充填鋼管柱、構造性能

\section{1. はじめに}

これまでの鋼板而震壁に関する研究には、主に二通りの流れがある。 一つは鋼製リブを鋼板に溶接する、また、コンクリートパネルで銅板を 挟むなどの面外補剛法を用いた、大変形時まで紡錘形の履歴性状を期待 できる耐震壁の研究である ${ }^{1,2}$ 。ももう一つは積極的な面外補剛をせず、銅 板を柱梁に接合した鋼板壁に関する研究である ${ }^{3)}$ 。日本で㬰用化されてい るのは主に前者で、面外補岡怯としては鋼製リブを溶接する方法が一般 的であり、多くのリブの設計に関する研究がなされている。後者の場合、 比較的小さな变形レベルて鋼板が面外に座届し、その後の履歷ループが 逆 S 字形となる。しかし、斜張力場が形成されるために、骨組との接合 部や鋼板に亀裂が生じる程の大変形レベルまで耐力は増加する。後者は 日本では敬遠されているが、北米では薄い鋼板を境界柱・梁に溶接した リブ無し薄鋼板而震壁が主に研究されている ${ }^{4}$. 5)。スリット入り鋼板而震 壁（ネリット壁）は、後者を、縦スリットに挟まれた部分（以下、この 部分を柱状部とよぶ) の曲げ挙動によって、製作・施工性を損なうこと なく、変形能力を高めた耐震壁と言える。

過去に筆者らは、単体のスリット壁の単調・繰返し水平加力実験（単 体実験 2078) および 1 層 1 スパンスリット壁付き鉄骨門形骨組の絽返し水 平加力実験 (門形骨組実験) 9)を行った。単体実験ではスリットの入れ方 およて鋼板の面外補哃法を実験変数として壁単体の履歴性状を調心、次 の式で単体のスリット壁の降伏耐力 $\left(Q_{n n y}\right)$ 、最大耐力 $\left(Q_{n \emptyset}\right)$ および初 期岡性 $\left(K_{\text {w }}\right)$ を算定でさることを示した $。$ 。

$$
\begin{aligned}
& Q_{\text {wiy }}=\frac{n t b}{3 \alpha} \cdot \sigma_{y} \\
& Q_{w t p}=\frac{3}{2} \cdot Q_{w+y} \cdot \alpha^{2}\left\{1-\cos \left(\frac{\sqrt{3}}{\alpha}\right)\right\} \text { (但し、 } \alpha \geq \frac{\sqrt{3}}{\pi} \text { ) }
\end{aligned}
$$

$$
K_{w t}=\frac{1}{\frac{\kappa(h-m l)}{G B t}+\frac{\kappa l}{G b t} \cdot \frac{m}{n}+\left(1+\frac{1}{\alpha}\right)^{3} \cdot \frac{l^{3}}{E t b^{3}} \cdot \frac{m}{n}}
$$

ここに、 $\sigma_{y}$ : 鋼板の降伏応力度、 $E$ :ヤング俰数、 $G$ : せん断弾性俰数、 $\kappa$ : せん断変形に関する形状俰数 $(=1.2) 、 b, l, t, h, B, n, m$ に関しては図 1(a) 参 照、 $\alpha$ : 柱状部のせん断スパン比の 2 倍 (= $l b)$ 。また、門形骨組実験に おいては、スリット壁は骨組に組み込まれた場合も䩚性の大きな挙動を し、剛性が比較的小さいものについては耐力・剛性を提案式で妥当に評 価できることを示した。

さらに、柱梁接合部形式およびスリット壁の有無・種類を変数とする3 層 1 スパンコンクリート充填鋼管（CFT）柱 H 形鐭梁骨組の一定軸力お よび斬増繰返し水平力載荷実験を行うた。実験の詳細と各圾験体の全体 挙動およひ構造性能については文献 10 で報告している。本稿では、文献 10 で報告した実験の結果に基いて、柱梁と壁の各々に作用する応力を調 べる。各層のスリット壁の弾塑性挙動および壁が骨組の挙動に及ぼす影 響を検証し、また、壁の耐力・剛性の評価法をについて述べる。なお、 本論文では、架構」は試験体全体を、「骨組」は試験体の壁を除いた

\begin{tabular}{|c|c|c|c|c|c|c|}
\hline (1) & (2) & (3) & (4) & (5) & (6) & (7) \\
\hline 試験体 & 接合部形式 & $m$ & $\begin{array}{c}b \\
(\mathrm{~mm})\end{array}$ & $\begin{array}{c}l \\
(\mathrm{~mm})\end{array}$ & $b / t$ & 面外補剛法 \\
\hline $\mathrm{CBN}$ & \multirow{4}{*}{ 鉛直スチフナ } & \multicolumn{5}{|c|}{ - } \\
\hline$\overline{C B} 10 \mathrm{~S}$ & & \multirow{4}{*}{2} & 42 & 235 & 9.2 & スチフナ \\
\hline $\mathrm{CB} 20 \mathrm{~S}$ & & & \multirow{3}{*}{86} & \multirow{3}{*}{168} & \multirow{3}{*}{19.1} & スチフナ \\
\hline $\mathrm{CB} 20 \mathrm{C}$ & & & & & & モルタルパネル \\
\hline CA20S & \multirow{2}{*}{ 外ダイヤフラム } & & & & & スチフナ \\
\hline CAN & & \multicolumn{5}{|c|}{-} \\
\hline SBN & 鉛直スチフナ & & & & - & \\
\hline
\end{tabular}
部分を表す。

\section{表 1 試験体}

注：試験体のうち、SBNは柱に中空鋳管を用いた試験体。本稿では特にふれない。

\footnotetext{
*1 九州大学大学院人間環境学研究院 助手・博士 (人間環境学)

*2. 九州大学. 名誉教授. 工博

*3 九州大学大学院人間環境学研究院 助教授・博士(工学)
}

Research Assoc., Graduate School of Human-Environmental Studies, Kyushu University, Ph. D.

Prof. Emeritus, Kyushu University, Dr. Eng.

Prof. Dept. of Arch., Kyushu Kyoritsu Univ., Dr. Eng. 


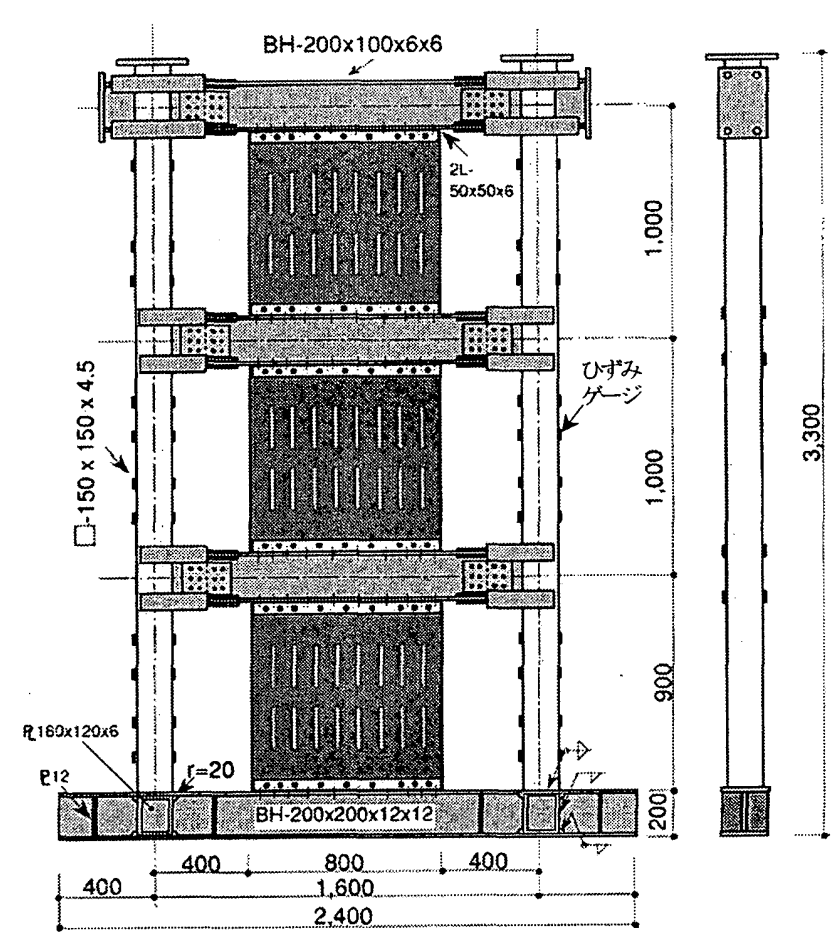

(b) 壁付架搆試験体（CB2OS）

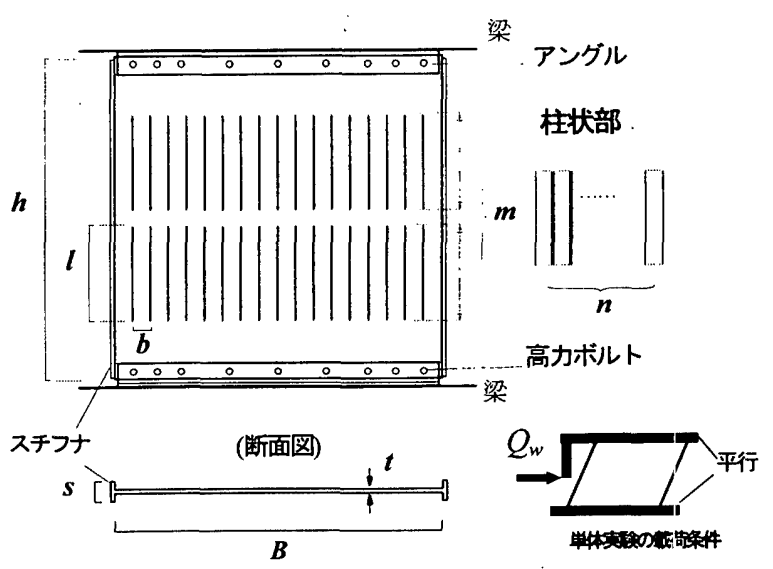

（a）スリット入り鋼板耐震壁

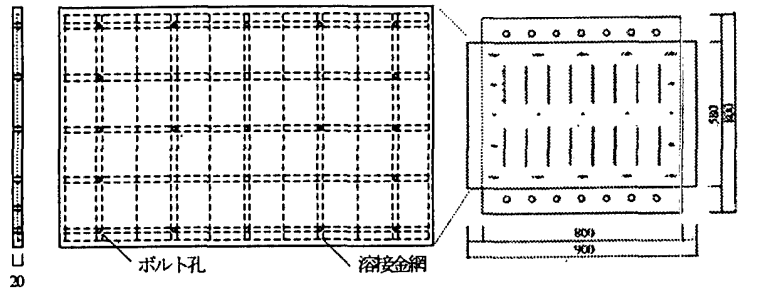

(c) モルタルパネル

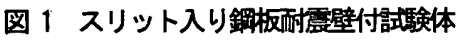

\section{2. 実倹概要}

\section{1 試酫体}

試験体は、表 1 に示す壁無し架構 3 体およひ壁付き架構 4 体の計 7 体 である。スリット壁が組み込まれた骨組は、図 lb に示す CFT 柱 H 形銅 梁の骨組であるが、柱梁接合部は外ダイヤフラム形式のもの (CA) と鉛 直スチフナ形式のもの (CB) の2 種類である。鉛直スチフナ形式柱梁接 合部については、文献 10 おび11 を参照されたい。圾験体名中、3 番目 の文字が N であるのは壁無し架構であることを示し、それ以外の圾験体 名中の 2 析の数字は柱状部の幅军比 $b / t$ 、最後の $\mathrm{S}$ おびCは鋼製スチフ ナおよびモルタルパネルで面外補剛した面震壁付き試験体であることを 示す。これらのスリット壁の単体性状を述べると、10S は、壁単体でも門 形骨組に組み込まれた場合でも、耐力が減少することなく大きな䩗性と エネルギー吸収能力を示し、提案式て耐力・剛性ともに適切に評価でき る。20S は耐力・剛性ともに $10 S$ より大きいが、層間変形角 $\mathrm{R} \geqq 1 \%$ での 面外変形恃大きく、履歷ループが逆 S 字形となる。このよなスリット 壁の面外補岡比に、鎙板を両面からせん断力を負担しないように挟み込む モルタルパネルを用いると、銅板壁の挙動は比㜞的大きな変形時まで履 歴ループが紡錘形の安定したものになる

銅板の寸法 (幅 $B=800 \mathrm{~mm}$ 、厚さ $t=4.5 \mathrm{~mm}$ 。 図 1 参照) およびスリット やスチフナの仕様は過去の実験 6-9) と同様である(スリットはレーザーカ ット、幅 $3 \mathrm{~mm}_{0}$ スチフナは耐震壁と同じ䤡板から製作、幅 $s=50 \mathrm{~mm}$ 、壁

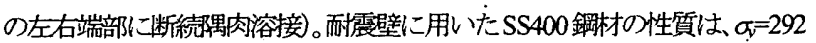
$\mathrm{N} / \mathrm{mm}^{2} 、 \mathrm{Y}=0.67 、 \varepsilon_{u}=26.3 \%$ で、過去の実験 ${ }^{6-9)}$ で使用した鋼材の $\sigma=275 \sim$ $290 \mathrm{~N} / \mathrm{mm}^{2} 、 Y=0.63 \sim 0.67 、 \varepsilon_{u}=30 \%$ 弱と同等である。CB20C の面外補剛に は、単体夷験 ${ }^{8)}$ と同様の、中央に溶接金網 (縦・横方向ともに鉄筋比は $0.5 \%$ 程度）を埋設した厚さ $20 \mathrm{~mm}$ のモルタルパネル2枚を用いた。パネルは
鋼板を両面から挟み込みボルトと 軽く締めたナットで鎆板に留め付 けられる。パネルが水平力を負担し ないよう、鋼板のボルト孔はルース ホールとなっている。

FEM 解析結果 ${ }^{(2)}$ によると、壁と 梁の接合部では、せん断力は接合部 の中央部で、また、壁からの曲げモ 一メントは壁左右端部の偶力とし て梁に伝達される。図1のように、 接合部は 9 本の M12 (F10T) の高 カボルト摩擦接合とした。中央の5 本のボルトで $20 \mathrm{~S}$ の計算酎力のせ

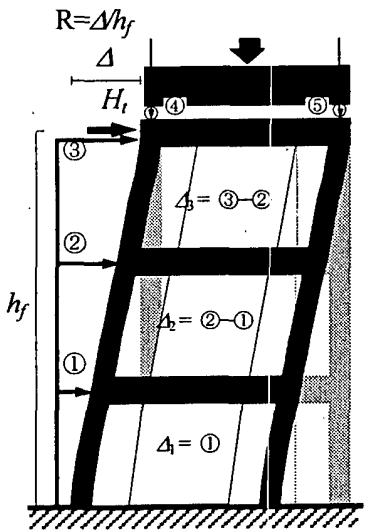

图 2 載荷条件・帚位測定 ん断力に、また、接合部左右端各 2

つのボルトで反曲点が壁の中央に位置する場合に接合部に生じる曲げモ 一メントに抵抗するよう設計した。アングルは門形骨組実験と同じ L-50×50×6 を用いた。

\section{2 載荷およひ測定方法}

載荷条件および測定装置を図 2 に示す。一定軸力の大きさは、鋼管の

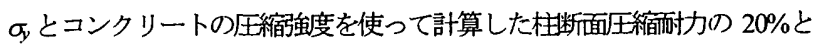
した。一定軸力は試験機で載荷梁を介して柱に載荷した。鉛直力!加力 点が移動しないように、ローラーで支持されたIビームに試験体を $\mathrm{PC}$ 銅 棒で固定し、I ビームに取り付けた油圧ジャッキを用いて 3 層の梁の断面 中心に水平力を載荷した。骨組の構面外の举動を抑制するために各層の 柱の中央の面外変形を抑制した。3 層の梁の軸心と基礎梁フランジ上面の 間の距離を $h_{t}(=2900 \mathrm{~mm})$ とし、架構の平均層間変形角 $\mathrm{R}$ は、 3 層梁の 


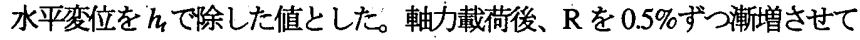
$\mathrm{R}=5.0 \%$ まで、各 $\mathrm{R} て ゙ 2$ 回の正負交番水平力を載荷した。

架構に載荷される水平力 $\left(H_{t}\right)$ をロードセルで、 $i$ 層の梁の水平変位を 図 2 の1) (3)の変位計で、また、柱の軸縮みを(4)および5)の変位計で測 定した。柱梁および接合部にゲージも貼付し、ひずみを測定した。図1(b) に柱フランジ中央に貼付したひずみゲージの一部を示している。大変形 時でも弾性状態にある柱の 4 断面のひずみデータと平面保持の仮定を用 いて、また、コンクリートの応力 $\left(\sigma_{\mathrm{c}}\right)$ 一ひずみ $\left(\varepsilon_{\mathrm{c}}\right)$ 関係を(4)式のよう
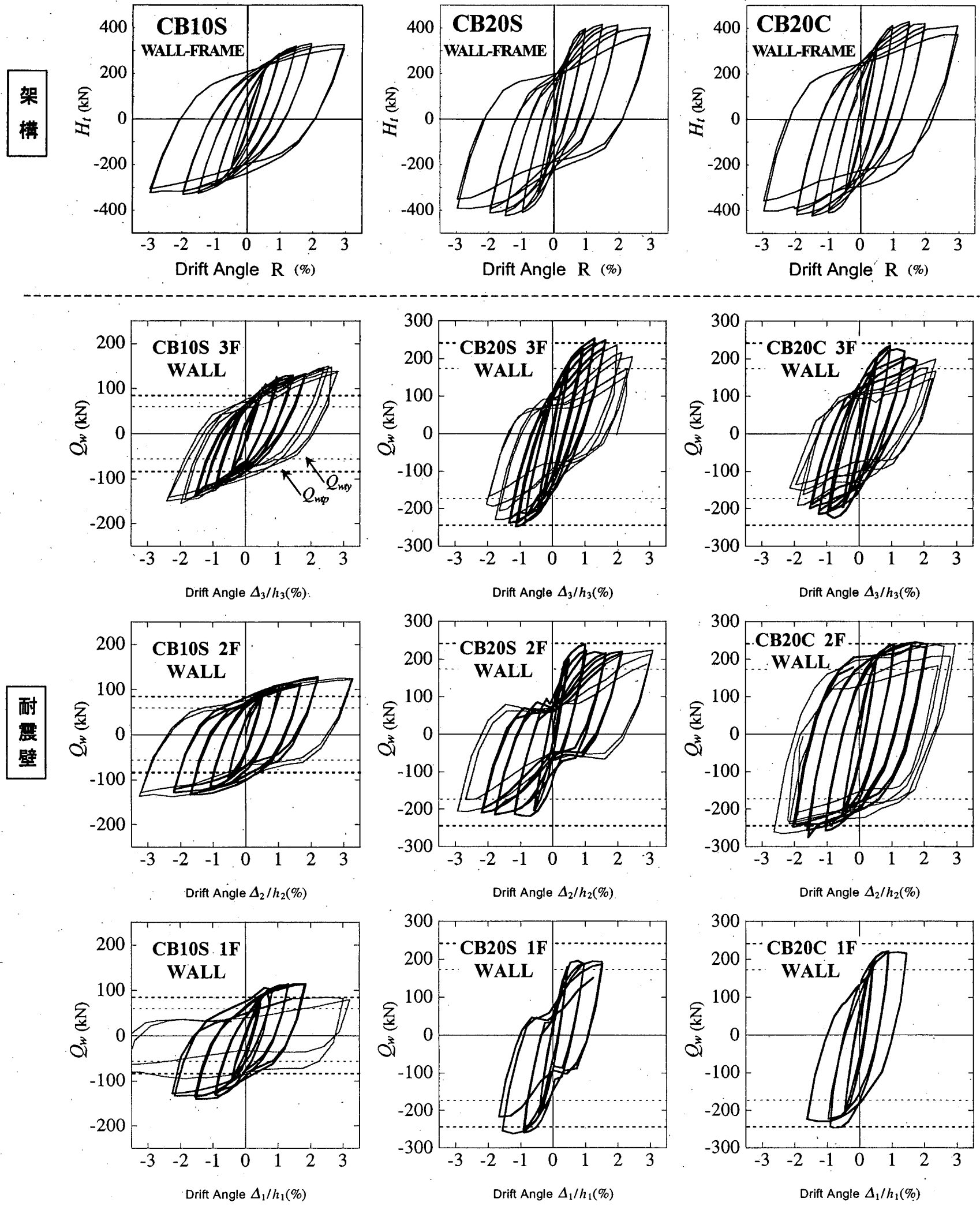

图 3 CB シリース壁付き架粠試験体と各層の耐震壁の水平力-層間变形角関係 
に仮定し、4断面のコンクリートの曲げモーメントを計算した。

$$
\sigma_{c}=\left\{2\left(\varepsilon_{c} / \varepsilon_{m}\right)-\left(\varepsilon_{c} / \varepsilon_{m}\right)^{2}\right\} \cdot f_{c}
$$

ここで、 $f_{c}$ はコンクリートの最大王縮応力度、 $\varepsilon_{m}$ はPopovicsによるコンク リートの最大ひずみ $\left.\left(\varepsilon_{m}=0.52 f_{c}^{025} \times 10^{-3}\right)^{13}\right)$ 。さらに、鋼管の断面 2 次モ ーメントおよびヤング率を用いて鋼管が負担する断面の曲げモーメント を計算し、各層で骨組の部分が負担する水平力 $\left(Q_{f}\right)$ を求め、 $H_{t}$ と $Q_{f}$ と の差を壁の水平力 $\left(Q_{w}\right)$ とした。

\section{3. 実䇦結果と考察}

柱梁接合部の形式による顕著な壁の挙動の変化は無かったので、CB シ リーズ試験体の結果に注目する。全CB シリーズ試験体は平均層間変形角 $\mathrm{R}=5 \%$ まで、急激な耐力劣化を生じることなく軸力保持能力を維持した。 以降 サフィックスiは $i(=1,2,3)$ 層に関する值であることを示す。

$\mathrm{R} \leqq 3 \%$ で壁付き架構試験体の載荷水平力 $\left(H_{t}\right)$ - 架構の平均層間変形 角 $(\mathrm{R})$ と各層の耐震壁に生じる水平力 $\left(Q_{w i}\right)$ - 各層の層間変形角 $\left(\Delta / h_{i}\right)$ 関係を図 3 に示す。また、壁無し架構 $(\mathrm{CBN})$ の $H_{r} \mathrm{R}$ 関係を図 4 に示す。 CBN 試験体に関して、ひずみデータを用いて2 章で述べた方法で求めた 水平力 $\left(Q_{f}\right)$ とロードセルで計測した $H_{t}$ を比較すると、両者が一致する のは $\mathrm{R}=3 \% 1$ 回目正側のサイクルまでである。これは柱鋼管内部のコンク リートの破壊が原因と考えられる。図 3 の各層壁については、計測断面

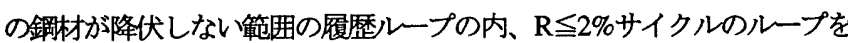
太線で、R>2\%サイクルのループを細線で示している。さらに、CB シリ 一ズ訌験体の軸縮みを図 5 に示す。

\section{1 弾塑性挙動}

骨組に関して述べと、CBN の場合、降伏は $\mathrm{R}=1 \%$ における 1 層風下 側（任縮側）柱脚の圧樎側フランジに始まり、 $\mathrm{R}=3 \%$ までには 3 層柱頭と 全ての層の梁端が降伏した。スリット壁の左右端での集中応力（4.2 で述 べる応力 $P$ ) によって梁の壁左右端部が降伏することはなかった。 $\mathrm{R}=2$ 〜 $3 \%$ 時に 1 層柱脚の外側フランジが局部座屈する。耐力は $\mathrm{R}=3 \% 1$ 回目 サイクル時でピークとなり、以降、P- $\Delta$ 効果を考虑した耐力線より大きな 負勾配て堿少する ${ }^{10}$ 。最大耐力時に柱梁接合部のボルトが滑り、この後 に履歴曲線はやや逆 $\mathrm{S}$ 字形になった。

壁付き架構試験体の骨組の柱には、より大きな変動軸力が生じるので、 降伏はCBN より 0.5\%程小さな層間変形角レベルで始まる。 1 層柱の局部 座屈もより早期に発生し、CB20S と CB20C の場合では、 $\mathrm{R}=1.5 \%$ 時で

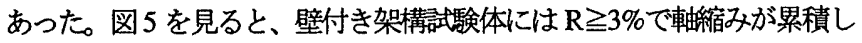
ているが、これは 1 層に集中している。壁付き架構試験体の各層骨組の 履歴ループは、剛性がやや大きくなることを除いて、どの試験体も概ね
$\mathrm{CBN}$ と同様で、 $\mathrm{R}=2 \%$ サイクル時の始めまでは完全な紡鍂形である。

以下に、スリット壁の弾塑性挙動についてまとめる。

CB10S : R=0.3\%時に而㨔壁か朔性化し始める。 $\mathrm{R}=0.5 \%$ サイクルて鋼板は わすが忙面外に変形する。 $\mathrm{R}=2 \%$ て壁のスチフナが構面外に変形し、2 層 の壁にせん断座屈モードのような波形の面外変形が生じる。このサイク ルの最後には、 2 層および 3 層の壁のスリット先端部に刍裂の発生が観察 された。履歷曲線は、而震壁の顕著な面外変形が始まる $\mathrm{R}=2 \%$ までは完全

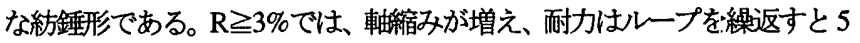
〜 7\%程度减少し、履歴曲線はやや逆 S 字形になる。

CB20S : 而震壁の柱状部端部は $\mathrm{R}=0.2 \%$ 時に降伏し始める。その後、 $\mathrm{R}=1 \%$ でまず 1 層の壁のスチフナが面外に変形し始める。その後、2 層、3 首と 続き、R=3\%までに全ての壁のスチフナが座屈する。履歴ループを見ると、

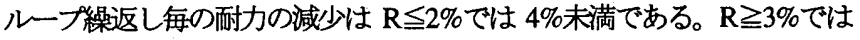
軸縮みとともに、壁の面外変形が急増する。 $\mathrm{R}=3 \%$ サイクルでは、耐力が 8〜14\%減少する。

CB20C : 初期変形時の弾塑性挙動はCB20S とほほ同じである。モルタル パネルは $\mathrm{R}=1$ 1.5\%でひびを生じるが、鋼板全面の面外変形を抑制する ので、その後の履歷ループはズチフナで補剛する場合よりも太い紡鍾形 である。モルタルパネルの破壊が進むにつれ、鋼板壁の面外変形が急増 し、履歴ループ形状は他のスリット壁と同様にスリップ型となる。

10Sおよび20Sの単体実験および3層架構実験のスリット壁の履歴ルー プの包絡線を図6に示して比較する。横軸は層間変位 $\left(\Delta_{w i}\right)$ である。大 変形時においては、鉛直方向の変形を骨組により抑制されるため、架構 に組み込まれた壁の方が耐力の劣化が小さい。b/t=10の壁は、いずれの層 の壁も単体実験の壁と同様の挙動を示している。 $b / t=20$ の場合、㓮性が大 きい載荷梁に取り付けられている単体実験の壁は、初期剛性が 3 層架構 実験の壁より大きい。また、1 層の壁は下端が載荷梁に接合されているの で梁の曲げ変形によ る剛体回転が上層よ り小さい。このため、 上層の壁より小さな 層間変形レベルで壁 が面外変形し、耐力少 化が生じる。

図7はR=1\%および $2 \%$ 載荷サイクルまで に架構が吸収したエ ネルギーを各層の骨 組と壁に分けて示し

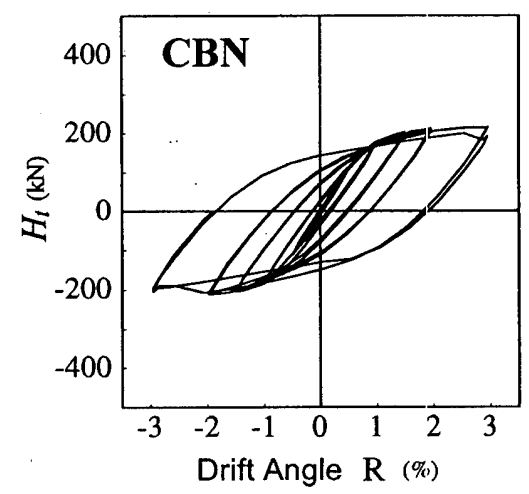

図4壁無し試験体の水平力-層間湾形角関係

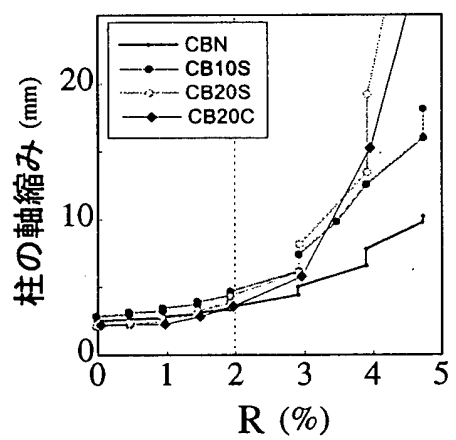

図 5 柱の軸縮み
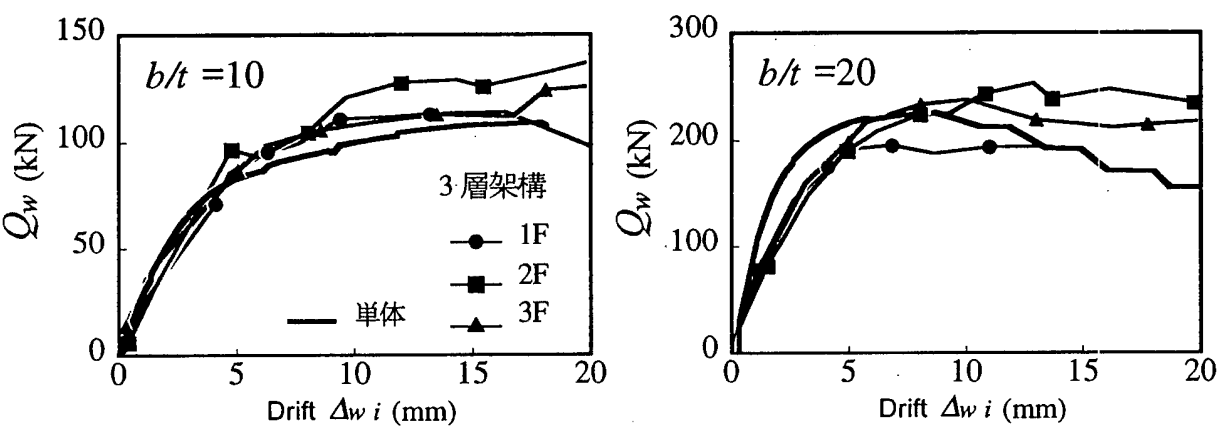

图 6 耐霞壁の履歴ループの包絡線 
ている。緥軸は壁無し架構 (CBN) の吸収エネルギー（E $\left.E_{f_{u}}\right)$ で壁付き架 構の吸収エネルギー $\left(E_{t}\right)$ を除した值である。壁付き架構では、骨組の塑

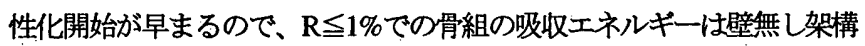
の 1.4〜1.5 倍である。これに対し、耐震壁は $\mathrm{R} \leqq 1 \%$ サクルでの架構に 吸収されたエネルキ゚ーのうち 57〜 75\%を吸収している。 $R \geqq 2 \%$ の変形 時では、骨組の塑性化が進み 一方、CB20S には面外变形が生じて履歷 ループも逆 S 字形になっているため、エネルギー吸収の負担は骨組と同 等となる。

\section{2 初期用性}

表 2 の(1)〜(3)に壁付き架構の $i$ 層における架構、骨組およひ䎟震壁の

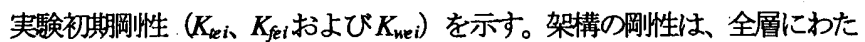
り、CB10S の場合で壁無し架構の概ね2 倍、他は約4 倍に増加している。 表 2 の(4)および(5)は壁が組み込まれていない骨組および単体壁の実験剛

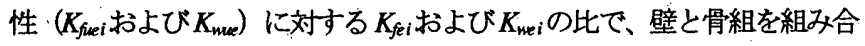
わせることによる骨組および壁の剛性の変化率を示す。壁を骨組に組み 込むと、骨組の剛性は全層概ね一様に増加し、一方、壁の剛性は特に 2 層と 3 層で減少している。これは、壁からの曲げモーメントによって梁 が変形するためである。

壁からの曲げモーメントは、図 8 に示すように壁の左右端部に集中的 に生じる鉛直方向の偶力 $P$ によって梁に伝達される。壁の反曲点はどの 層においても壁の高さ中央に位置すると仮定すると、 $P$ と壁に作用するせ ん断力 $Q_{w}$ の間には次の関係がある。

$$
P=Q_{w} \cdot h /(2 B)
$$

但し、記号は図 8(b)参照。
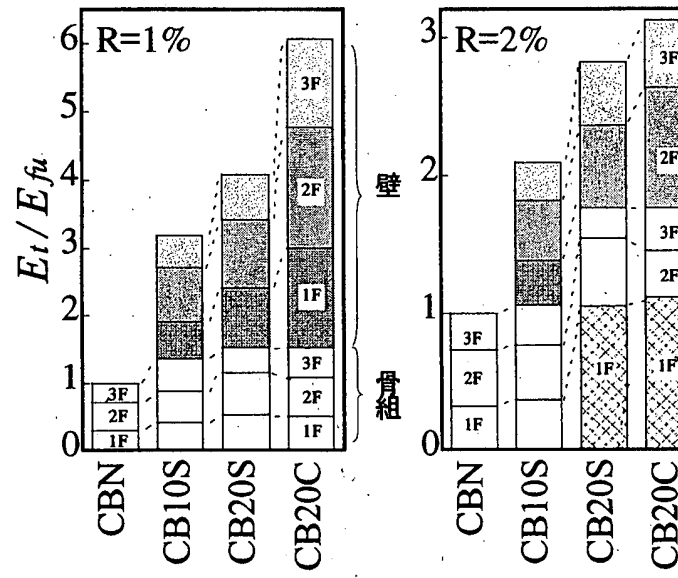

图 7 エネルギー吸収量の比較
表 2 の(のは、部材の実測寸法を用いてたわみ角法によって計算した骨

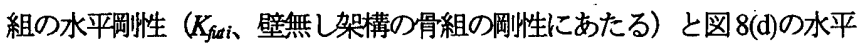
力 $Q_{f}$ と $P$ が作用している骨組の剛性 $\left(K_{f i}\right.$ 、壁付き架構の骨組の剛性にあ たる）を比較した值 $\left(K_{f i t} / K_{f a i}\right)$ である。表 2 (4)の実験結果と比較すると、 $K_{f i} / K_{f i t}$ は $P$ が大きい (壁の剛性が大きい) 場合は 3 割程過大だが、Pが 比較的小さい $10 S$ の場合は実験值と一致する。

図 8c)の単純梁の変形による回転角 $\theta_{w}$ は、(5)式の関係を使うと(6)式で求 められる。

$$
\theta_{w}=\frac{Q_{w}}{48 E I_{b}} \cdot \frac{h_{c}}{l_{b}} \cdot\left(l_{b}-B\right)\left(2 l_{b}-B\right)
$$

(6) 式の $\theta_{w}$ を壁の㓮体回転角として壁の水平剛性 $\left(K_{\mathrm{wfi}}\right)$ を求める。但し、 1 層の壁は下端が固定端であるので $\theta_{v} に 0.5$ を乗じた値を用いる。壁の杗 験剛性 $K_{\text {wei }}$ の $K_{\mathrm{wffi} i}$ に対する比を表 2 の(7)に示す。(7)を見ると、実際は水 平力 $Q_{f}$ による梁の変形が壁の剛体回転を抑制するので、 $P$ が小さい

（CB10S）壁の剛性については1〜2割過少評価となっているが、他の壁 については妥当な值を与えている。連層で用いられる壁の剛性は、上記 のようにして求められる剛体回転角 $\left(\theta_{w}\right)$ を考慮することで評価できる。

\section{3 耐力}

表 2 の(8)〜(10)に、架構と各層の骨組およひ耐震壁の最大耐力（ $H_{k}$ と $Q_{\text {fii }}$ および $Q_{\text {mei }}$ )を示す。最大耐力は $\mathrm{R} \leqq 2 \%$ で正負両側の耐力の平均と した。

表 2 の(11)は、単体奏験での耐震壁の耐力 $\left(Q_{m e e}\right)$ に対する $Q_{\text {mei }}$ の比で ある。壁の㓦力は単体実験の場合よりやや大きく、特に $10 \mathrm{~S}$ の場合は 1.2 倍になっている。これは、骨組に組み込まれた壁は鉛直方向の変形が拘 束され、面外変形が単体実験の場合ほど大きくならないためである。

表2 の(12)は壁無し架構（CANまたはCBN）と壁の単体夷験の耐力の 累加に対する壁付き架構の実験耐力の比 $\left(H_{t} /\left(Q_{\text {fue }}+Q_{\text {mue }}\right)\right)$ である。20S や

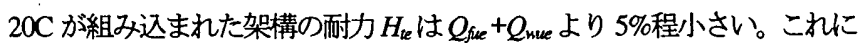
は二つの要因がある。一は壁付き架構弪験体の骨組には、壁無し架構 より大きな変動軸力が生じ、塑性耐力が 5\%程小さくなっていることであ る ${ }^{10)}$ 。もう一つ要因は、壁と骨組それぞれの耐力が最大となる時の層 間変形レベルが異なることである。10S の耐力は骨組と同様に $\mathrm{R}=2 \%$ まで 増加し続けるので、架構全体の耐力 $\left(H_{k}\right)$ は骨組と壁の耐力の累加 $\left(Q_{f w}\right.$ $\left.+Q_{\text {mue }}\right)$ と同等である。一方、 $20 \mathrm{~S}$ および $20 \mathrm{C}$ の壁は $\mathrm{R}=1 \%$ で耐力がピーク に達した後に減少するが、 $\mathrm{R}=1 \%$ の段階では骨組の耐力は最大の $80 \%$ 程度 である。このような壁の耐力は、設計で想定する変形の大きさを考慮し て評価しなければならない。

図9は、 $\mathrm{R}=2 \%$ 時の 3 層架構の壁と同等の層間変形が生じた時の単体実 験の壁の耐力 $\left(Q_{n 22 \%}\right)$ を(1)式の降伏耐力 $Q_{n v y}$ で除した值 $\left(Q_{n 22 \%} / Q_{n m y}\right)$ を

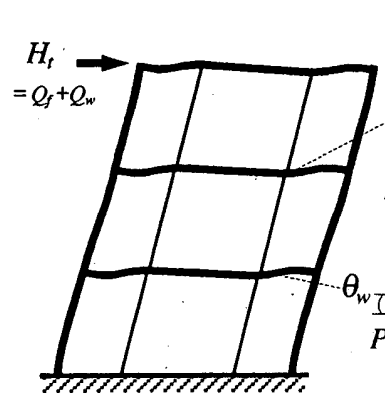

(a) 架楧

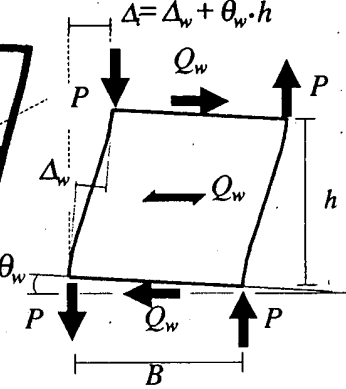

(b) 壁の変形 $\cdot$ 応力

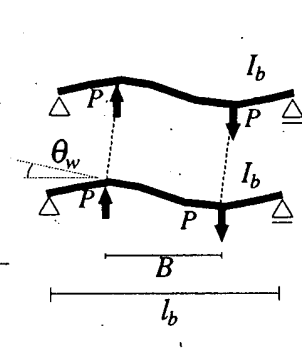

（c）壁の㒺体回転

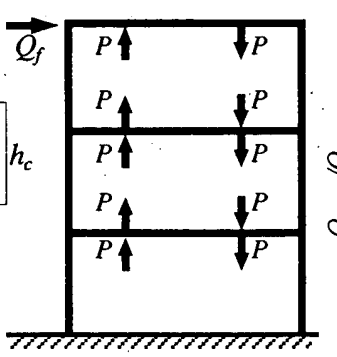

d）骨組の変形

图 8 骨組と耐震壁の応力伝達・变形

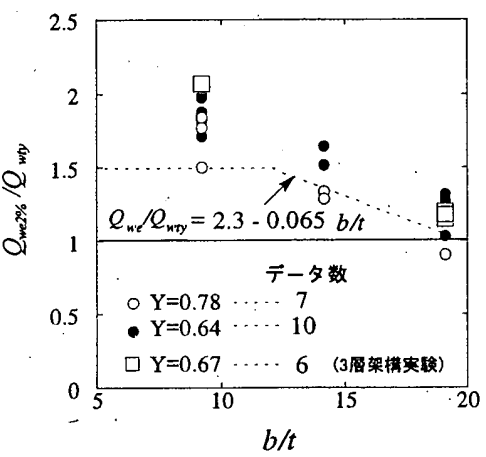

图 $9 \mathrm{R}=2 \%$ 時の耐力 
表 2 能性と尉力

\begin{tabular}{|c|c|c|c|c|c|c|c|c|c|c|c|c|c|c|}
\hline \multirow[b]{2}{*}{ 試験体 } & \multicolumn{4}{|c|}{ 実験剛性 $(\mathrm{kN} / \mathrm{mm})$} & \multicolumn{4}{|c|}{ 剛性比 } & \multicolumn{3}{|c|}{ 実験耐力 (kN) } & \multicolumn{3}{|c|}{ 耐力比 } \\
\hline & 階 & $\begin{array}{c}(1) \\
K_{t e i}\end{array}$ & $\begin{array}{c}(2) \\
K_{f e i}\end{array}$ & 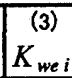 & $\begin{array}{c}(4) \\
K_{f e i} / K_{\text {fue }}\end{array}$ & $\begin{array}{c}\text { (5) } \\
K_{\text {we i }} / K_{\text {wue }}\end{array}$ & $\begin{array}{c}(6) \\
K_{f i i} / K_{\text {fut } i}\end{array}$ & $\begin{array}{c}(7) \\
K_{w e i} / K_{w f t}\end{array}$ & $\begin{array}{c}\text { (8) } \\
H_{t e}\end{array}$ & $\begin{array}{c}(9) \\
Q_{f e i}\end{array}$ & \begin{tabular}{|l|}
$(10)$ \\
$Q_{w e i}$
\end{tabular} & $\begin{array}{c}(11) \\
Q_{\text {we } i} / Q_{\text {wue }}\end{array}$ & $\begin{array}{c}(12) \\
H_{t e} /\left(Q_{\text {fue }}+Q_{\text {wue }}\right)\end{array}$ & $H_{t e} /\left(Q_{f u e}+Q_{w 2 \%}\right)$ \\
\hline \multirow{3}{*}{ CA20S } & 3 & 73 & 23 & 50 & 1.38 & 0.48 & 1.82 & 0.94 & \multirow{3}{*}{368} & 158 & 237 & 1.05 & \multirow{3}{*}{0.95} & \multirow{3}{*}{1.07} \\
\hline & 2 & 78 & 23 & 55 & 1.34 & 0.53 & 1.88 & 1.03 & & 144 & 238 & 1.05 & & \\
\hline & 1 & 117 & 39 & 78 & 1.46 & 0.75 & 1.56 & 1.10 & & 142 & 237 & 1.05 & & \\
\hline \multirow{3}{*}{ CB10S } & 3 & 49 & 27 & 22 & 1.24 & 0.77 & 1.28 & 1.05 & \multirow{3}{*}{332} & 202 & 135 & 1.24 & \multirow{3}{*}{1.01} & \multirow{3}{*}{$\$ .09$} \\
\hline & 2 & 52 & 25 & 27 & 1.23 & 0.94 & 1.29 & 1.29 & & 210 & 131 & 1.21 & & \\
\hline & 1 & 64 & 39 & 25 & 1.21 & 0.89 & 1.21 & 1.11 & & 212 & 127 & 1.17 & & \\
\hline \multirow{3}{*}{ CB20S } & 3 & 80 & 29 & 51 & 1.30 & 0.49 & 1.82 & 0.95 & \multirow{3}{*}{420} & 180 & 251 & 1.11 & \multirow{3}{*}{0.94} & \multirow{3}{*}{1.04} \\
\hline & 2 & 86 & 29 & 56 & 1.45 & 0.55 & 1.88 & 1.06 & & 210 & 228 & 1.01 & & \\
\hline & 1 & 118 & 47 & 71 & 1.45 & 0.69 & 1.56 & 1.00 & & 209 & 229 & 1.01 & & \\
\hline \multirow{3}{*}{$\mathrm{CB} 20 \mathrm{C}$} & 3 & 78 & 30 & $\overline{48}$ & 1.37 & $\overline{0.46}$ & 1.82 & 0.89 & \multirow{3}{*}{427} & 226 & 230 & 1.02 & \multirow{3}{*}{0.96} & \multirow{3}{*}{1.06} \\
\hline & 2 & 80 & 26 & 53 & 1.30 & 0.52 & 1.88 & 1.00 & & 182 & 261 & 1.15 & & \\
\hline & 1 & 131 & 44 & 88 & 1.36 & 0.85 & 1.56 & 1.23 & & 210 & 235 & 1.04 & & \\
\hline
\end{tabular}

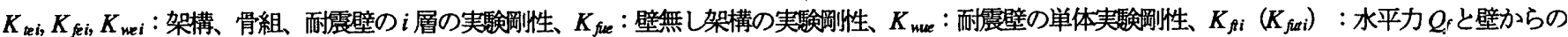
鉛直方向の応力 $P$ が作用する $\left(Q_{f}\right.$ のみが作用する) 骨組の $i$ 層のたわみ角法による計算剛性、 $K_{\mathrm{uff}}:(5)$ 式の壁の㓮体回転角を考慮した耐震壁つ計算剛性。

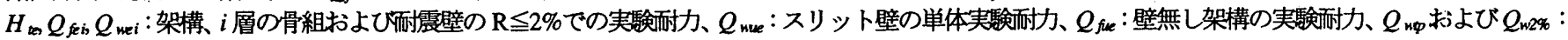
スリット壁の計算耐力（(2)式およびフ式による）

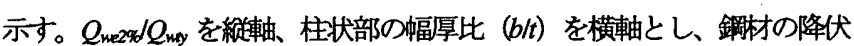
比 Y が異なる試験体を○と○とで区別して示している。また、口は3 層 架構実験の值である。図9 の破線が示すように、 $Q_{n+22} / Q_{n y}$ とb/tには負の

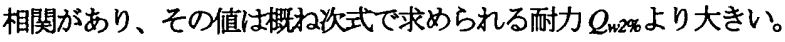

$Q_{w 2 \%}=\min \left(Q_{w t p}, Q_{w t y} \cdot(2.3-0.065 b / t)\right)$

表2の(13)は壁無し架構の実験耐力 $Q_{f u e}$ と $Q_{m 2 \%}$ の累加に対する R=2\%まで での架構の実験耐力の比で、概ね 1 に近い値を示している。スリット壁 の耐力は、 $\mathrm{R}=1 \%$ 程度の変形を許容する場合は(2)式で、 $\mathrm{R}=2 \%$ 大变形ま で許容する場合の壁の耐力は、(7)式で算定すべきである。

\section{4. 結論}

一定軸力下の連層スリット入り鋼板而震壁付き 3 層 1 スパンのCFT 柱

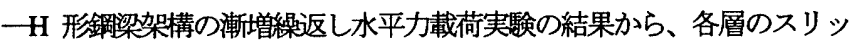
卜壁（10S、20S および20C）の挙動と壁が骨組（架構から壁を除いた純 フレーム部分) の弾塑性挙動に及ぼす影響を調べ、以下の知見を得た。

1. スリット壁の $\mathrm{R}=2 \%$ までの挙動は、 1 層壁の岡性が他層よりやや大きい ことを除いて、全層にわたり概小等しい。 $\mathrm{R}=3 \%$ 以上の大変形レベルで は柱の軸樎みが特に 1 層で堛加し、スリット壁の面外変形も 1 層で大 きくなるが、その時も急激な架構の耐力劣化は起きない。

2. 骨組に連層スリット壁が組み込まれると、骨組（架構から耐震壁を除 いた純フレムム部分) の岡性は 1.2〜1.4 倍に増加するが、スリット壁 の有無およひ種類によって、骨組のヒンジ形成位置が変わるような大 きな弾塑性挙動の変化や骨組の履歷ループ形状の顕著な変化は生じな い。

3. 連層で骨組に組み込まれたスリット壁は、壁の左右端において梁と壁 の間で伝達される偶力に起因する梁の変形により、剛体回転する。壁 の剛性は剛体回転を考慮して概放評価できる。下端が剛接合されてい る 1 層壁の剛性算定に関しては、2 層壁の剛体回転の $1 / 2$ を考虑すれば 安全側に評価できる。

4. 架構内でのスリット壁の耐力は、概ね単体の壁の耐力と等しく、終局 耐力評価式(2)は妥当である。但し、柱状部の幅厚比 $b / t$ が大きいスリッ

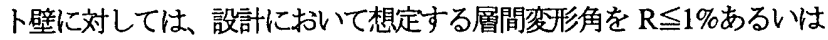

$\mathrm{R} \leqq 2 \%$ 条件で、評価式(2)と(7)を使い分けると耐力を適切に評価でき る。

\section{謝辞}

本研究㤬平成 $11 \cdot 12$ 年度科学研究費補助金 (基盤研究(A)(2)、研究代 表者: 松井千秋）の助成を受けて行った。実験に関して、久島昭久技官、 津賀山健次技官、有働文久技官、川口晃技官、松岡直人技官、柳田幸久 氏（国土交通省）、犬丸啓一郎氏（福岡県庁）、西川卓氏（構造計画研 究所）、小沢英二氏（愛媛県庁）、中島由香里氏（西日本鉄道）に御協 力頂きました。有り難うございました。

\section{青文赫}

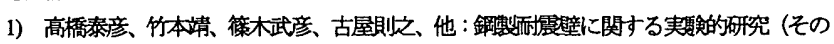
1-6)、日本建筑学会大会学術譜演梗概集 構造系、pp.917-922、1970.9、.pp.407-412、 1971.11

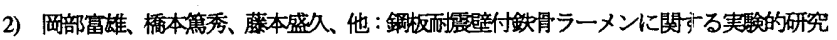

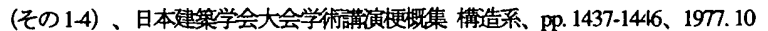

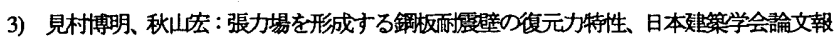
告集第260号、pp.109-114、1977.10

4) Cacoese, V., Elgaaly, M. and Chen, R: Experimental Study on Thin SteelPlate Shear Walls under Cyclic Load, Journal of Structural Engineering, ASCE, Vol 119(2), pp. 588-605, 1993.2

5) Driver, R G., Kulak, G. L, Kennedy, L and Elwi, A. Cyclic Test of Four-Story Steel Plate Shear Wall, Joumal of Stuctural Engineering, ASCE, Vol 124(2), pp. 112-120, 1998.2

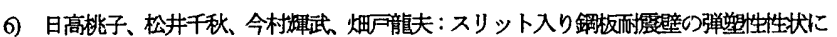

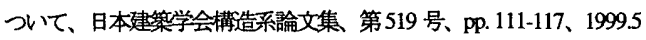

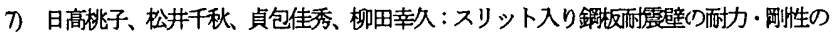

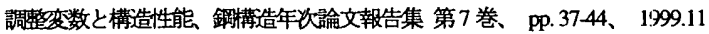

8) Htraka, T., Matsui, C.: Strength and Behavior of Steel-Concrete Composite Beaing Wall, Proc. ASCCS6, pp. 153-160、2000.3

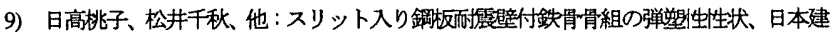
学学会構造系論文集 第 534 号,pp. 153-160, 2000.8

10）松井千秋、堺純一、他：CFT3 層骨組の弹塑性变形性状に関する実験的研究、日本建 築学会構造系論文集 第 572 号,pp. 177-183, 2003.10

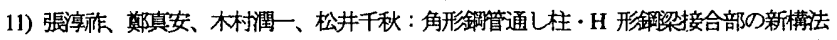
に関する研究 銅構造年次論文報告集，第7 巻、pp.37-44、1999.11.

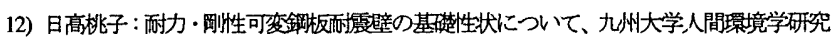
院 博士論文、2001.1

13) Popovics, S., "A Numerical Approach to Complete Stress-Strain Curve of Concrete," Cement and Concrete Research, Vol 3, pp.583-599, 1973 